\title{
Article
}

\section{Israel and the Crisis of Radical Blackness}

\author{
Christopher T. Fisher (1)
}

check for

updates

Citation: Fisher, Christopher T. 2022. Israel and the Crisis of Radical Blackness. Genealogy 6: 19. https:// doi.org/10.3390/genealogy6010019

Received: 16 December 2021

Accepted: 3 February 2022

Published: 25 February 2022

Publisher's Note: MDPI stays neutral with regard to jurisdictional claims in published maps and institutional affiliations.

Copyright: (C) 2022 by the author. Licensee MDPI, Basel, Switzerland. This article is an open access article distributed under the terms and conditions of the Creative Commons Attribution (CC BY) license (https:// creativecommons.org/licenses/by/ $4.0 /)$.
History Department, School of Humanities and Social Sciences, The College of New Jersey, Ewing, NJ 08628-0718, USA; fisherc@tcnj.edu

\begin{abstract}
This article examines the reach of Black Internationalism, a dialogue on race, politics, and modernity nurtured by Black nationalists in the United States, between 1971 and 1974. It focuses on Israel's encounter with the topic and how Israeli political leaders neutralize its effects. Israel, one of America's closes Cold War allies, faced three explosive movements with ties to the discourse and politics of Black Internationalism - the Israeli Black Panthers, the Black Hebrews, and the Jewish Defense League. Each group challenged the narrative of inclusion the nation cultivated since its inception. Israel's ability to manage the crisis of Black Internationalism demonstrates the topic's global reach in the final stages of the Cold War, but also its limitations.
\end{abstract}

Keywords: International Blackness; Israeli Black Panthers; Black Hebrews; Mizrahi; Israel; Black Panthers; Black Nationalism

\section{Introduction}

When Saadia Marciano, a Moroccan-born Jew, stood with 300 hundred protesters in the streets of Jerusalem on 3 March 1971 and boldly charged to the city's police, "We know our rights ... You've trampled them long enough! That's over now!", he was claiming that Israel had a race problem. At the same rally, another protester screamed, "Why does the town spend millions on a new marble theater, when the money ought to be spent on

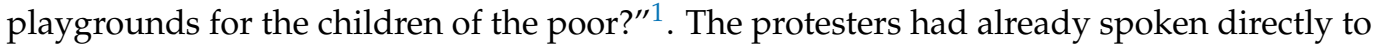
the people of the city through leaflets scattered about the neighborhood:

Residents of Jerusalem['s] slums: Lately newspapers are publishing daily revelations of shocking facts about the situation of thousands of families in the poor neighborhoods of the country in general and of Jerusalem in particular ... They reveal the suffering of human beings living in mind-numbing and depressing poverty subsisting in conditions of hardship and want ... Without proper education and employment for the residents of the poor neighborhoods, despair, hardship and the shortcut to crime are [certain]. ${ }^{2}$

That day, Marciano introduced the Pantherim Shechorim, or Israeli Black Panthers, ${ }^{3}$ a new political movement that borrowed audaciously from its namesake in the United States. ${ }^{4}$ Premised on the spectacle and symbolism of African American Blackness, Israel's Black Panthers drew support from the country's underclass, the Mizrahi or North African Jews, and Sephardim or Non-European Jews, ${ }^{5}$ who heeded Israel's call to Aliyah (translated as "ascend" in Hebrew) or to leave from Africa, India, and Arab states and return to their religious and ancestral home. Part of Israel's appeal to Aliyah was the centrality of faith and Jewishness as an ethnic identity, not a race. But by 1971, a different sense emerged among a significant portion of the Mizrahi community, especially the youth, that implied that their alienation from Israeli society transcended Judaism. In the fierce identity politics of the post-Civil Rights moment, where African Americans activism shifted from racial integration to Black liberation in solidarity with the Third World and everything played out spectacularly in the international press, tapping into the concept of an imagined Blackness 
gave the Mizrahi youth the language, style, and methodology to challenge the narrative of Israel's pluralistic society.

At roughly the same time that Marciano and the Black Panthers protested racism in Israel, an unlikely group of some 400 African Americans, expatriates from Chicago's Southside who called themselves Black Hebrews, settled in the city of Dimona, much further south in the Negev Desert. They also heeded Israel's call to Aliyah, but for them, Israel was their spiritual home that had been lost in history. By their definition of Hebraism, Israel was a Black nation and geographically part of an African territory that stretched deep into the Levantine Middle East. Over the next year, 1500 more Black Hebrews would make the exodus as part of their leader's-Ben Ammi Ben-Israel-prophetic vision to reclaim Israel as the rightful homeland for children of the Atlantic Slave Trade. Modifying the earlier traditions of Black Zionism advanced by African American leaders who range from Henry McNeal Turner and Edward Wilmot Blyden to Marcus Mosiah Garvey, Black Hebrews incorporated Pan-Africanism into the Black nationalist sentiment of the 1960s and gave both a spiritual touch. ${ }^{6}$ Arriving in Israel at a critical moment in its historical development, the Black Hebrews would fascinate, frustrate, and trouble questions of race and Jewish identity.

When the two groups are taken side by side, in one fateful year, Israel's pluralistic society acquired a Black problem. In 1971, two distinct Zionisms had converged in Israel and took on the symbolism of Blackness in an era when the language, politics, and imagery of color racism dominated global news. The Mizrahi fashioned their notions of selfdeterminate inclusion from the sound bites and anecdotes of America's Black Panthers and deployed them against the state of Israel, turning symbolism into substance, as Blackness became a counterpoint to Israeli politics and culture. Whereas the Black Hebrews carried their Blackness like luggage from Chicago to Liberia to the Negev Desert and forced themselves into the social drama playing out between 1967 and the Yom Kippur War. While the issue of Israeli Blackness would fade from public consciousness within three years, there is little doubt that for a brief time, Israel was one of the Blackest places in the Middle East.

The alternating versions of Israeli Blackness, as an imagined community in the case of the Mizrahi Jews who made up the Black Panthers and as a sociohistorical fact in the case of the African Americans who comprised the Black Hebrews, pressed the Israeli state to clarify exactly what pluralism meant and where it rested in the social forces that shaped the Israeli modernity. Israeli Blackness raised troubling questions for its citizens and the Jewish Diaspora about how much of the Western world could spill over into the homeland, a reflex of what Amy Kaplan has called "America's Israel" (Kaplan 2018) and Melanie McAlister has cited as America's "moral geographies" (McAlister 2001, p. 4), and whether the project of Jewish Zionism could be appropriated by other groups and turned back on itself.

Israeli Blackness has been a backdrop to a recent trend in scholarship that focuses on International Blackness. ${ }^{7}$ Over the last two decades, scholars in history, Middle Eastern Studies, American Studies, and literature have explored the dynamics of race and Blackness in Israel as a representation of the social consequences of globalism, transnationality, and the legacies of the long 1960s. ${ }^{8}$ In much of the literature, the Blackness of African American Hebrews and Mizrahi Jews ${ }^{9}$ is a curious aside, which is especially unusual given what Keith Feldman identifies as the new "cartographies" created by reconstructed borders in the post-WWII period and what Alex Lubin calls the multiple "geographies of liberation" caused by postwar decolonization movements (Lubin 2014, pp. 8-10). These interpretations highlight the rise of a global imaginary premised upon a notion of International Blackness that stood as a counterpoint to the long history of Western modernity, a history that Paul Gilroy associated with the Black Atlantic.

The crisis in Israel, however, suggests looking beyond Gilroy's geography (McAlister 2001, pp. 121-24). It also affirms the uniqueness of this historical moment and how each group used Blackness as a metaphor for resistance. In Israel, both groups sought to challenge systemic power, hierarchy, and privilege, but they also advocated for selfdeterminant inclusion within the Israeli state, and despite caustic rhetoric, neither was 
interested in Israel's demise. Even the name Black Panthers, which appealed to the politics of Blackness and the social history of race and slavery in the West, particularly the United States, implied more than met the eye.

Yet, as this study demonstrates, there were definite limits to the effectiveness of Blackness as a global counterpoint to Western modernity. ${ }^{10}$ After the initial shock of having its own confrontation with Blackness, Israel leveraged the crises in ways that proved especially adaptive. In the end, Israel's response suggests that the reaction to International Blackness may have been more formulaic than the literature admits. Prime Minister Golda Meir employed tactics that frustrated, discredited, and effectively neutralized the groups and used the crisis to reaffirm the Israeli state.

\section{How the Mizrahi Became Black}

By 1971, Israel was an epicenter in the Near Eastern World, and when Saadia Marciano and his cohort of Black Panther protesters took to the streets of Jerusalem, they were not only invoking the name of a movement foreign to Israeli politics, but they also were forcing the unpleasant realities of Israel's state-building program into plain view. At some level, for this group of Moroccan and Arab Jews, to call themselves "Black" was unusual. Even the Non-Aligned Movement, led by North African and Asian leaders who sought to unite Black and Brown people under the banner of postcoloniality and Afro-Asian unity, did not conflate the two identities (Lee 2010; Prashad 2007). However, Israeli Black Panthers had a nuanced understanding of Blackness that transcended Western definitions of color. To them, as Israel Shahak noted in 1973 and Sami Chetrit would affirm years later, "Black" was a protean concept manufactured from the modernity-producing forces of the West. It encompassed colonialism, racialism, orientalism, and predatory capitalism, all at once, and the byproduct of this arrangement, the Israeli youth would maintain, ascribed Blackness to the alienated other (Shahak 1973, pp. 152-54; Chetrit 2009, p. 70; Cohen and Shemesh 1976 , p. 20). Black, therefore, was a reaction to powerful forces that presented themselves as white.

Indeed, when considered in the context of Israel's own history, the audacity of the Israeli Black Panthers' Mizrahi leadership is not so farfetched. After twenty years of being racialized as Black and compared to "Negroes" by Israel's dominant group, the Ashkenazi, the Israeli Black Panthers were, in a sense, speaking in the native tongue. Likewise, Mizrahi appropriation of Blackness is less outrageous when considered against the spectacle of Black nationalists in the United States rebelling against the global hegemon and the way that movement captivated the international community. Seeking a global analog to name their condition and make their oppression legible to a world that was finally watching and listening, the Musrara youth found inspiration in the Black freedom struggle.

Beyond its symbolism, the racialization of Mizrahi in Israel has its own uniquely tragic history that dated back to 1948, the year of Israel's birth as a nation. For twenty-three years following its war for independence, Israel's Aliyah policy granted all Jewish people the "Right to Return", which resulted in a wave of immigration from all over the vast, diverse, and diffuse Jewish Diaspora. An unspoken assumption of Israel's first Prime Minister, David Ben-Gurion, was that the new settlers would be "Jewish of people in Europe."11 The need to quickly fill his infant nation, however, compelled Ben Gurion to seek Jewish immigrants elsewhere, and thus, he looked to Africa and the Middle East. Solving the question of Israel's population did little to assuage Ben Gurion's disdain for Sephardic Jews, especially the Mizrahi from Morocco, of whom he groused: "The culture of Morocco I would not like to have here."12

Prime Minister Ben Gurion's disdain for the Mizrahi followed a prejudice that placed those immigrants in a second-tier status and denied them access to state aid, housing, and an adequate education in a manner reminiscent of America's Jim Crow segregation. Like Blacks in the United States, the Mizrahi were valued primarily as cheap manual labor. One immigration agent in North Africa, writing about what he was witnessing among the Jewish community in Israel, put the emerging conditions in foreboding terms: "There is 
gross discrimination now, ... This is an Israeli problem ... it might result one day in the creation of two racial groups in a single country."13

What deepened the "Israeli problem" was the demographic transformation taking place in the new country. Between 1948 and 1956, just over half of the Jews who immigrated to Israel were from Africa, Asia, and Arab regions, which included the Mizrahi from North Africa. Because of the immigration differentials, two narratives of Israeli identity emergedthe original pioneering settlers, the Sabra, who were held in high esteem, and the chaff who followed. In one of the most damning anti-Mizrahi statements, Haaretz journalist, Arye Gelblum, maligned them in racialist language that was meaningful to the Ashkenazi elite:

This is a people (The Mizrahi) whose primitivity sets a record, their level of education borders on total ignorance, and worst yet is their lack of ability to absorb anything spiritual. For the most part they are only a tad better than the general level of the Arab, Negro, or Berber neighbors ... In the African living quarters in the camps you will find filth, card playing for money, drunkenness, and prostitution ... In total there are more than half a million Jews in North Africa, all of them candidates for Aliyah. Have we considered what would happen to the state [of Israel] if this would be its population? ${ }^{14}$

In the successive waves of immigration, first among the Sephardi, next the Polish, and then the Ashkenazi from Soviet territories in the 1970s, Israel's Jewish Agency, which was responsible for settling migrants, sorted the new arrivals into one category or another and gave them state provisions that proved woefully disproportionate. The disparities were readily apparent to Mizrahi immigrants, who, in the early years, found themselves stranded in destitute transit camps in towns such as Haifa and Jaffa or neighborhoods such as Musrara. These were in desert areas, such as the Negev, or in strategically vulnerable places close to the borders of hostile neighbors, such as Jordan, and the conditions in the camps ranged from sparse to inhumane, as some lacked adequate sanitation, running water, electricity, healthcare, and access to education (Shohat 1997, pp. 38-40; Segev 2018). As Misha Rabinowitz, an agent for the Jewish Agency, noted with some alarm, "the present immigration, given its makeup and condition, with its lack of preparation and organization, will place the State of Israel in an intolerable situation. In time to come, we may witness a Moroccan ghetto." 15 Thus, as the civil rights revolution got underway in the United States, there was a growing sense among the Mizrahi that they were being segregated under conditions that resembled the Jim Crowing of Blacks in America.

As the Mizrahi moved out of transit camps and settled into permanent neighborhoods, their alienation had developed into the type of combustible racialized anger endemic to America's largest cities. The signs were evident as early as July 1949, when roughly 400 Mizrahi protested their poor working conditions and lack of food in Jerusalem and Tel Aviv. Underground journals, such as Mapam-Party-sponsored al Mirsad, connected their plight to other movements for racial equity and decolonization circulating throughout the West from scholars such as Frantz Fanon. It is unsurprising, therefore, that when the Mizrahi exploded against the state, it played out against the local police, who represented Israel's daily abuses and indignities. Mizrahi leaders crafted a document of protest, called the Pardes Hanna Manifesto, that borrowed the anti-colonial language of the emerging global Left. Named for one of the largest transit camps, the Manifesto spoke in the Hegelian terms of the master-slave dialectic to describe the relationship between Mizrahi and camp authorities. The group who drafted the Manifesto listed five demands, one of which was an end to their "humiliating" segregation in the transit camps. ${ }^{16}$ Sensing that the ground was shifting beneath them, some officials such as David Horowitz, the director of the Ministry of Finance, began to ring the alarm about ethnic divisions:

The population in the camps is becoming a sort of second nation, a rebellious nation which views us as plutocrats. This is incendiary material ... It's dynamite ... There is also a special attitude emerging on our part toward them; we are beginning to harbor an attitude of superiority. ${ }^{17}$ 
It would not be long before protest escalated to outright rebellion in the Wadi Salib neighborhood of Haifa in 1959.

The Wadi Salib Rebellion transpired under conditions that would have been very familiar to African Americans in the United States. On the evening of 8 July 1959, responding to a disorderly conduct complaint, two local police officers shot and paralyzed a drunken Moroccan man, Ya'akov Akiva El-Karif. Tensions had been building between Mizrahi residents and local police for over a decade in the ma'abarot. Increasingly, the community saw them as an occupying force. Like the Detroit riot of 1943, El-Karif's shooting touched off an explosion of violence from the Mizrahi community and became a flashpoint for discrimination that caused the protests to spread from one town to the next, continuing for over two months and eventually reaching as far as south as Beersheba.

Israel's crackdown on protests and its ban on protest literature did not keep the Mizrahi from posting signs that leveled charges of racism against the state and Ashkenazi. What the anonymous immigration agent from North Africa feared in 1948 had come to pass-Israel developed into a society with separate cultures. The Mizrahi's growing oppositional culture, however, would name it in bold and graphic terms as the nation moved from Wadi Salib protests into the 1960s:

The days are over when [O]rientals would gratefully thank their European masters for any morsel thrown to them in the form of a longer day at school or Uncle Tom in the Knesset. There is growing, instead, the feeling that 'we don't want any favors' but, rather, demand what is ours by right ... To repeat the quotation in last month's bulletin: 'Whitism breeds Blackism.'18

To them, their Blackness was a response to Ashkenazi whiteness, and by the 1960s, this sentiment would come out as a full-throated rebuke of the prevailing racial order.

\section{Radical Blackness}

When Israel launched a preemptive strike against the Arab states in 1967 and subsequently defeated them in six days, it changed the geography, composition, and priorities of the state from stability and nation building to security and solidarity. The calls for unity among the Israeli people met an undercurrent of racialist resentment among the Mizrahi that was only deepened by a postwar economic boom that seemed to favor another wave of Ashkenazi immigration, this time from Soviet Russia. Once again, Israel seemed to be promoting another group at the Mizrahi's expense.

Nineteen sixty-seven would become a crucial inflexion point for Israel and the politics of International Blackness. Two things happened almost simultaneously. First, on the eve of the Six Day War, Israel developed an inchoate Black identity, particularly among the youth and Israeli Left. Second, the Black rights movement in the United States made its fateful transition from the nonviolent direct-action philosophy of Dr. Martin Luther King, Jr., to structuralist critique of systemic white racism, which they called Black Power, offered by the Student Nonviolent Coordinating Committee (SNCC). In both instances, what started as a structural critique quickly morphed into something bigger that was oftentimes ideological, cultural, angry, and demanding. In the American case, Black Power would be partially responsible for the birth of the Black Panther Party for Self-Defense, the namesake of Saadia Marciano's group from the streets of Musrara four years later. Huey P. Newton and Bobby Seale's nascent program to confront and monitor systemic racism among the police in Black communities would eclipse SNCC to become principally associated with Black Power, but the Black Panther Party would also outgrow its local roots and become an international phenomenon one year after its founding in 1966.

Yet the effects of Black Power were even larger than what SNCC and the Black Panther Party seemed to indicate, because Black Power activated a much older critique of global white racism from other Black nationalist organizations that had laid dormant since the 1920s-Black Zionism. Since the nineteenth century, emigration movements have attracted considerable attention among African Americans who considered the United States beyond redemption, and at its apogee, Black Zionism mobilized thousands of Black people to look 
to Africa as a homeland. While literary scholars have illustrated the scope and depth of this reaction to white racism and colonialism among people of color, it is historians who have teased out the populist dimensions of that response in the form of Pan-Africanism, Marcus Garveyism, and the Black Panther program of Intercommunalism. Instead of seeing the Black diaspora as geographically isolated in the Atlantic, they characterize Black Zionism as an aspiration of the folk who took the assumptions of Black Power to its logical end-emigration to their own land (Blain 2017; Landing 2002).

Black Power, therefore, re-energized this important thread in African American counterpoint politics, and in 1967, it set in motion another curious intervention in Israeli politics that would give added meaning and complexity to its confrontation with Black Pantherismthe arrival of Hebrew Israelites. Alternatively, known as the Black Hebrews, the Hebrew Israelites would utilize the principle of Aliyah for their own purposes and emigrate to Israel in 1969. The idea originated two years earlier, in the fateful events of 1967, when Ben Carter took the Hebraic name Benn Ammi Ben-Israel (Ben Ammi, as he was called) after joining the Hebrew Israelites in 1960 and assuming the role of Rabbi. In the angry social and political climate of 1967 America, Benn Ammi had a prophetic vision from the Angel Gabriel to lead "the Children of Israel among African Americans" out of the ghettoes of Chicago to the "Promised land"(Kurtis 1981). The peculiarity of the vision and its instruction, which blended traditional Zionist tropes with the symbolism of the Black Church, spoke to the larger distinction of the sect. The open-ended, ad hoc nature of their faith and racialized identity would perplex Israelis at the very moment they were struggling with Mizrahi Blackness.

The Black Hebrews were just one of many African American factions who traced their lineage to Judaism. Historically, however, those sects trace back to the nineteenth century when African American religiosity rose with emancipation. Following Reconstruction, the Black Hebrews wended their way through the hightide of Black cult and Zionist activity of World War I to the social activism the 1960s. Many of its founders, whether from Harlem, Philadelphia, or Chicago, were instrumental in Marcus Garvey's Universal Negro Improvement Association (UNIA) and the back-to-Africa movement, but they tended to tinge their message of Black Zionism with mystical themes from the Bible. A common feature among Black Hebrew groups was a direct link back to Harlem's Commandment Keepers of the Living God. This was the largest of the sects to appear in the WWI period, but it was also the catalyst for other groups who branched out from Garvey's movement after his deportation, including the one in the Chicago arm of the movement that would produce Ben Ammi and his sect, the Original Hebrew Israelite Nation (later called the Kingdom of Yah).

In a town thick with Black religious movements, most notably the Nation of Islam and Pentecostalism, Hebrew Israelites gained a loyal following among Southside Blacks. Part of their appeal was how they incorporated key elements of the other religions into their interpretation of Judaism. The core feature of their faith was a story of exile and diaspora, just like orthodox Judaism. However, like the Nation of Islam, it was inflected through the lens of American slavery and segregation to explain both the Blackness of African Americans and the tragedy of racial oppression. To Black Hebrews, African Americans descended from Ten Lost Tribes of Israel who were exiled from the Holy Land in the fifth century for not keeping the law or Torah. Scattered into West Africa and swept up in the Atlantic Slave trade, Black Hebrews claimed they were sold into American bondage and remade into Black Christians. As Rabbi Wentworth Arthur Matthew, one of the progenitors of Black Hebraism, explained in the 1950s:

During slavery they took away our name, language, religion, and science, as these were the only possessions the slaves had, and they were pumped full of Christianity to make them docile ... All so-called Negroes are the lost sheep of the House of Israel which can be proven from scripture and they all have birthmarks that identify their tribe. ${ }^{19}$

In his own writing, Ben Ammi would make that mytho-historical link clear: 
The transfiguration of the African Hebrews (Sons of God) into a non-people (negroes) [sic] exemplifies the epitome of soul transformation. The people who were once rulers of advanced civilizations like Songhai, Egypt and Mali have descended into the pits of the most barbaric societies. ${ }^{20}$

The path back to reclaiming one's true identity, Black Hebrews maintained, went through close observation of the Torah, which could lead to a revelatory experience on the same scale as an epiphany or Christian awakening. While there was great variation among the different expressions of Black Hebraism, from how closely they observed the rabbinical text produced after the Torah to whether they accepted Jesus Christ as a messiah, certain attributes and practices were common among them. All camps or nations, as they called themselves, incorporated Hebrew as the formal language (Key 2014, p. 55); observed the sabbath, with men using the day to fast in some groups; adopted a kosher diet with some, such as Ben Ammi's group, becoming vegans as a way to follow Kashruth or the Hebrew laws on food; kept most traditional Jewish festivals and days of worship; practiced the ritual of circumcision; followed the family and social practices of the Torah, such as niddah, where intercourse is forbidden for seven days after a women's menstruation; required men to cover their heads with a cap or kippot; Hebraized their names; and promoted strict piety as a condition of faith. ${ }^{21}$

Despite their similarities, there were significant differences between Black Hebrews and traditional Jewish beliefs and practices, such as disputes about the Hebrew calendar, the names of some Jewish festivals, and, among some branches, most notably Ben Ammi's, the role of the rabbinate. As Ben Ammi would later blithely instruct a Jewish interviewer: "Our customs are different from yours. We believe only in the Torah, not what was added later."22 Likewise, many Black Hebrews had personal roots in the Jim Crow South, and all of them were reared in the Black Church, which caused them to fuse the Torah with the stories, spirituality, and faith practices of Pentecostalism and Black Baptist traditions. They took the soulful gospel-style of music that is characteristic of the Black Church and borrowed other practices, such as call-and-response preaching and giving testimony during their sermons. Ben Ammi not only considered music the sonic expression of divinity, even before the word, but also a distinct manifestation of Blackness:

Our music has kept our eyes and remembrance on our heritage-the Holy Land (Jerusalem, the Jordan, Jericho) Israel. It kept us in constant supplication before our God. It kept us continuously praising His name and His mighty works. During chattel slavery, music was our friend. ${ }^{23}$

Even in dress and cultural practices, Black Hebrews adapted African American style, as it was the tendency of Ben Ammi's group to serve vegan renderings of "soul food" and wear dashikis as ceremonial garb. Some of the distinctions, however, were more consequential and opened Black Hebrews to charges of antisemitism. None more so than the belief of Ben Ammi's group that the Ashkenazi were neither chosen nor legitimately entitled to the holy land of Israel. As Ben Ammi informed, "We represent another paradigm and we are telling all Jews, Israelites, that you're Africans. That means that if you're a Jew, an Israelite, you're not European." ${ }^{24}$ The discrepancy was a consequence of being birthed in counterpoint exceptionalism of Black radical politics, where they recast Blacks in the role of Jewish exiles and remapped Africa to include the Levantine Middle East (Fernheimer 2009, p. 28). By rewriting the traditional Jewish story, with mystical embellishment to explain the color distinctions between Blacks and Ashkenazi and shifting the geographical landscape of the African diaspora, Black Hebrews not only challenged Ashkenazi Chosen-ness, they also created, as Alex Lubin writes, a new geography for liberation (Lubin 2014, pp. 8-9). The effects of this cognitive shift were deep and personal for Ben Ammi, who was always very clear, especially when he first arrived in Israel, that neither he, nor his group, considered themselves Jews (Landing 2002, p. 91; Key 2014, p. 40; Chireau and Deutsch 2000, p. 74).

By ritual and behavior, therefore, Black Hebrews were a unique mixture of Zionism, Black nationalism, and prophesy. Few could have guessed that they would break out of 
their cloistered bubble in the Southside of Chicago and create an international crisis, but in the explosive social conditions of the late 1960s, even the unthinkable was possible. Like everything else with his group, when Ben Ammi decided to lead his own exodus out of the United States in 1967, it was premised on a mixture of scripture and Black nationalism. Socially, America was on a knife's edge, and Ben Ammi believed the conditions were particularly acute in Chicago's Black community, which struggled with high rates of drug addition, prostitution, crime, and disease (Weisbord 1975, p. 23).

However, the global signs were there as well. Israel's victory in the Six Day War affirmed Ben Ammi's belief that the pathway was being set before them. Yet, his first step in the direction of exodus was not to Israel, but instead to Liberia. Following his vision of the angel Gabriel, Ben Ammi and members of the Original Black Hebrew Nations purchased land in Liberia and left the United States create their own settlement. Ben Ammi claimed they went to Liberia first to confront their Blackness and exorcise its vices. He would later describe the experience as a kind of cleansing:

During the Six day [sic] War in Israel in 1967, the African Hebrews journeyed to Liberia, settling 110 miles outside Monrovia, to purge themselves of the decadence that had been the way of life for them in America... After cleansing themselves of the niggerisms [sic] and negative habits acquired during their captivity in America and after learning to live, love and trust one another like human beings, the Hebrew Israelites had become fit to begin the work of building God's Kingdom. ${ }^{25}$

One of the group's leaders, Minister Ahmadiel Ben Yehuda, would later describe the time in Libera as "our wilderness experience; leaving modern Egypt" 26 .

The difficulties of surviving in the West African backcountry made the group's survival uncertain. Some members returned to the United States in frustration and exhaustion, but Ben Ammi and his core leadership decided to take the next step of emigrating to Israel a year later. After surveying the country with Hezekiah (Charles) Blackwell, Ben Ammi left him behind to work on a kibbutz and facilitate their emigration. In 1969, Blackwell used Israel's Law of Return to initiate the process in the Ministry of Absorption to bring in the first five Black Hebrews. After being placed in a ma'abarot in Arad, they settled in apartments in the town of Dimona in the Negev desert ${ }^{27}$. Between August and December, their numbers would grow to forty-four before rising to roughly 300 by the time they became a concern for the Israeli government in $1971{ }^{28}$.

When Israeli officials became aware that they had misidentified Black Hebrews as the Falasha, Black Jews from Ethiopia, it was too late. The issue Prime Minister Golda Meir's government faced, which was compounded by the sudden arrival of Black Panthers, was what to do with the Black Hebrews. In a strange twist of fate, competing claims of Blackness converged on Israel three years after it fortified its borders and consolidated itself as a state. Meir understood that the answer to both could upset the recent gains it had made in international stature, particularly with its allies in the United States. The Black Panthers and the Black Hebrews knew what was at stake as well, which compelled them to stand firm on their goals.

\section{The Point of Crisis}

Saadia Marciano and the Israeli Black Panthers continued their public relations battle by continuing to protest the government's mistreatment of Mizrahi. In posters and pamphlets, they accused the Meir administration of singling out Mizrahi children for exclusion and that it was part of a larger pattern of oppression carried out in non-Ashkenazi neighborhoods by agents of the state. "Residents of Jerusalem slums", one pamphlet stated,

Lately the newspapers are publishing daily revelations of shocking facts about the situation of thousands of families in the poor neighborhoods of the country in general and of Jerusalem in particular ... They reveal the suffering of human beings living in mind-numbing and depressing poverty subsisting in conditions of hardship and want ... The school services in these neighborhoods are shoddy, 
the buildings dilapidated. The classes are overcrowded. There is a shortage of equipment, uniforms, fixtures (accessories). Without proper education and employment for the residents of the poor neighborhoods, despair, hardship and the shortcut to crime are victorious. ${ }^{29}$

Inside Israel, the initial reaction to the protest was shock and containment, but as the American Jewish Committee's (AJC) report on the incident indicates, to Jewish advocacy groups outside Israel, the protests barely deserved notice: "In one of the poorer quarters of Jerusalem, the youth ... set up a gang and style [sic] themselves after the 'Black Panthers.' It seems that the name appealed to them, but there the similarities end." The report continued, "Were it not for the name, nobody would much care." 30

The Israeli Black Panthers employed the symbolism of Blackness because the Israeli youth knew it had international currency. That made it important to Israeli leaders. Yet, they also knew "Black" had its own meaning related to Ashkenazi and Mizrahi relations within the state. As Ella Shohat has identified in her work, "[T]he choice of the name 'Black Panther' also ironically reverses the Ashkenazi reference to Mizrahi as 'black animals.'" (Shohat 1997, p. 5) To the Israeli Black Panthers, the critique about their use of Blackness was disingenuous because it was already firmly established as a pejorative; they were simply playing the hand they were dealt in their efforts to integrate into the Israeli system. Feeling that public attention was waning in June and July, they staged one of their largest protests in August 1971 (Bernstein 1984, pp. 142-44).

As pressure mounted on Israel's government, it faced another crisis that kept the issue of Blackness in the news. That October, the Black Hebrews demonstrated against Israel's refusal to admit its members into the country. Since 1969, complaints from locals in Dimona made Israel's Ministry of Interior suspicious of the group's identity. After an investigation and a refusal to convert any of its members to Judaism through halacha or Jewish law, the Ministry rejected arriving members. Ben Ammi responded by accusing Israel of anti-Black racism in the international media, touching off tensions that would compound the problems of the Black Panthers. Just as important for the Meir administration was the arrival of Jewish militant and Zionist firebrand, Rabbi Meir Kahane of the Jewish Defense League (JDL), among the 31,000 America Jews who made Aliyah to Israel between 1967 and 1973 (Rebhun and Waxman 2000, p. 67).

Since the 1950s, African American and Jewish activists had formed the nucleus of what became the civil rights coalition in the United States. Leaders as diverse as Martin Luther King, Jr., Bayard Rustin, and Roy Wilkins worked with Jewish organizations, such as the Anti-Defamation League (ADL) and AJC, to press the cause of civil rights as an expression of post-World War II human rights (Young 1972, p. 72). After the Six Day War, the bonds of that relationship began to fray when the youth of the movement, SNCC and the Black Panther Party for Self-Defense openly rebuked Zionism. That July, the pages of SNCC's newsletter opened the debate with an asymmetrical attack on Israel titled, "The Palestinian Problem: Test Your Knowledge." The questions started with the sardonically rhetorical phrase, "Did you know", and were answered with a mixture of historical anecdotes and virulently anti-Semitic stereotypes ${ }^{31}$. Listed as thirty-two offhand "facts", SNCC painted a dark history of Palestinian expropriation and exclusion at the hands of Israelis and incorporated it into a radical critique of America and the West (Lubin 2014, pp. 60-65; Feldman 2005; Malloy 2017). After SNCC's “Third World Roundup", one by one, Black nationalist leaders began speaking out against Israel, with Stokely Carmichael, SNCC's former chairperson, arguing in 1968: "[I]f white people who call themselves revolutionary or radical want our support, they have to condemn Zionism." 32 The Black Panther Party in America, itself becoming more focused on building an international network against the triple forces of capitalism, racism, and imperialism, joined SNCC's attack on Israel, writing in its newsletter: "The Israel government is an imperialist expansionists power in Palestine ... The term, Israel, is like saying racist United States, it has the same policy as the US Government in the Middle East" 33 . Black Panther Party co-founder, Huey P. Newton, would try to mitigate the damage by walking back the group's virulently antisemitic 
statements by attributing them to internal strife within the organization ${ }^{34}$, but by then, the damage had been done, and it set off the likes of Rabbi Meir Kahane, who formed the Jewish Defense League (JDL) in 1968 as a response to Black anti-Zionism.

The JDL consciously appropriated the militancy, style, and tactics of Black Power and translated it into "Jewish Power" (Feldman 2005, pp. 118-22). Rabbi Kahane's confrontational style included a paramilitary program of arms training, martial arts, and explosive making for JDL members, all of which gave him national recognition as a renegade. As its membership grew to 5700, so did the militancy of his actions (Phillip 1969). In December 1969, Rabbi Kahane directed his JDL to intervene in the conflict over who should control Brooklyn's Bedford-Stuyvesant public education system. It was an extension of the battle that played out nationally between local Blacks and Jews over who should run the school board in New York's Oceanhill-Brownsville district, a crisis that had descended into antiBlack and anti-Jewish vitriol (Ravitch 2000). Within seven months, the Hasidic community in Williamsburg, which is adjacent to Bedford-Stuyvesant, would invite the JDL in to patrol, and after, one of its members accidently hit and killed a Black girl with his vehicle. Upon his arrival, Rabbi Kahane issued a warning to Blacks: "If they think Jewish blood is cheaper than anybody else's, let them know that Jews can riot, too" ${ }^{35}$. More than an idle threat, it was a promise, and as the Federal Bureau of Investigation (FBI) noted in its report on Kahane, he used Williamsburg as evidence that his program worked. According to the FBI, Rabbi Kahane told an audience in Chicago that November:

In the New York Williamsburg District, where thousands of poor Jews live, a Chassidic [sic] Jew accidently ran over a black girl with his truck. The courts freed him of responsibility. In spite of the court's decision, the Blacks went on a rampage against the Jews. Calls came into the JDL headquarters for help. Why did the poor Williamsburg Jews call the JDL instead of B'nai B'rith? Because they know they would come down-They did come down-and conquered. Blacks stopped their terrorism. ${ }^{36}$

Rabbi Kahane's comfort with extremism placed him on the outer edge of mainstream politics. What elevated him to the status of a renegade was his conviction on charges of domestic terrorism in a plot to attack Soviet diplomats in July 1971. His decision to make Aliyah to Israel two months later, therefore, came under a very dark cloud of a political flight and had the potential to turn Israel's confrontation with the politics of International Blackness into something much more dire.

Once in Israel, Rabbi Kahane's introduction to national politics was to denounce the Black Hebrews and rally opposition against them in Dimona. At an open session in the city's movie theater, Rabbi Kahane excoriated the Black Hebrews as racists and outsiders who threatened Israel's honor. He emphasized one aspect of the group's beliefs to make his point-their claim that true Hebrews were Black, and Israel was part of Africa's historical geography:

If they say God is Black that is God's business. But if they say Moses and Abraham were Black then this is a reflection on our ancestry ... They deny us the Divine right to our country ... and no nation cherishing its honor can stand such an insult.

While he denied accusations of inciting violence, that was the impression left on those in the room. ${ }^{37}$

The presence of Rabbi Kahane increased the urgency for the Meir administration to act, but it also helps explain what gets muted in the literature-that Israel's response to the crisis of International Blackness was a choice between two untenable options. Faced with a choice of extremism and violence against Mizrahi dissidents and Black Hebrews on one side or total admission that it had a Black problem on the other, Israel chose a third path-neutralization. When the Israeli Black Panthers threatened a hunger strike at the Wailing Wall in April 1971, Prime Minister Meir used a meeting with the group at her office to launch her plan. 
From the start, it was evident to the Israeli Black Panther representatives-Saadia Marciano, Reuven Aberjil, and David Levy - that there was an underlying motive. Prime Minister Meir had little interest in talking about the social issues that produced the threat, only the symbolism of their Blackness, their troubled background, and why they would support an antisemitic movement from the United States. ${ }^{38}$ They reached no resolution at the end, only hardened feelings. However, for Prime Minister Meir, it set in motion the narrative to diminish the Panthers' hold on the public's imagination.

Roughly one month later, after a Panthers protest in Jerusalem during the Moroccan celebration of Mimouna that follows Passover, Meir met with them again. There, when confronted with more claims about Mizrahi poverty and police abuse, she shifted the focus to Israeli unity, saying "The state of Israel's strength is in our unity, and there can be no worse or more horrible disaster than division, then I fear we approach the danger point." 39 Later, Meir's olive branch moment quickly disintegrated because of an offhanded remark to the media that the Panthers were "not nice people" for their violent confrontations with the police. Those simple words inflamed a public backlash against the administration and led to a charged exchange with Shaul Ben-Shimon, a member of Meir's Labor Party, over the controversy. ${ }^{40}$

Despite the unfortunate optics of the meeting, Prime Minister Meir set the foundation for marginalizing the Black Panthers. In addition, the administration would continue to undercut Panthers' claims by investigating charges of discrimination in housing, state benefits, and schooling in poor neighborhoods; encouraging divisions within the group, leading to the creation of a splinter group, the Blue and White Panthers (the colors of the Israeli flag); inducting the Black Panthers into the military for compulsory service; increasing efforts to bring in Soviet immigrants for humanitarian reasons and to offset the Mizrahi plurality; and refusing to negotiate directly with them. Tactically, it was an effective neutralization plan.

The Israeli Black Panthers fought back, and for a while, it seemed that they were gaining traction. At the start of 1972, they waged a disruption campaign at the World Zionist Congress (WZC) in Jerusalem and gained legitimacy as they were granted access to the floor, even when the body denied Rabbi Kahane and the JDL. The Panthers also tried to forge bonds with the US Black Panther Party at a conference in Florence, Italy in April 1972. Even as they broadened their platform to include more reformist demands that delivered food to the poor, such as their program Operation Milk, and pressured the Knesset to include "Panthers Budget" provisions in national funding plans, they were fading from the public's vision.

The Meir administration took a more direct approach with the Black Hebrews. Everything hinged on the question of their status as Jews, an issue the Ben Gurion administration tried to settle in the 1950s by recognizing three determinants-Halachic conversion, marital adoption, or a biological link through matrilineal descent. Each condition made it relatively easy to tag Ben Ammi and the Black Hebrews as outsiders. Just as importantly, as David Geller of the AJC reported, "In a way, Ben Ami [sic] himself had taken the Government off the hook ... [by claiming that] his group were 'Israelites by nationality, not Jews by religion' - which spared the Government the task of deciding whether they were real Jews." ${ }^{41}$ Officially, the question of their Jewishness and right to emigrate dragged through the courts for another year before the High Court settled the matter in the Leonia Clark and others $v$ the Minister of Interior. In the end, Israel could not bear the optics of expelling a large cohort of African Americans, so they let the Black Hebrews stay in legal limbo (actually, until 2003) (Weisbord 1975, pp. 34-36; Fernheimer 2009).

Self-inflicted wounds only deepened the plight of Black Hebrews. Besides living in destitution because of their growing numbers, limited dwellings, exclusion from government settlement aid, and prohibition from working because of their status as noncitizens, they also succumbed to internal conflicts that resulted in the murder of one member and conviction of two others. Another member was deported for theft at a supermarket in Arad, though she frankly admitted when asked about why she committed the crime: "I 
was hungry." 42 These transgressions further sullied the Black Hebrews' reputation, but they also fed into some of the most trenchant stereotypes about African American criminal behavior.

Fighting to maintain control internally, and under attack by the Meir administration, Ben Ammi took desperate measures that met uneven results. In one instance, he sought to publicize their dire condition by staging thefts of food from a market in Dimona for the media. He also lobbied members of the Congressional Black Caucus to pressure Israel into granting them full citizenship rights on humanitarian grounds. In another instance, he fought back against the state's characterization of the Black Hebrews as outsiders by showing the social worth of their Blackness to locals. Black Hebrews survived this difficult moment by selling vegan food that they touted as "Kosher Soul Food" or "Soul Veg" and producing trinkets and clothing inspired by Black styles from the United States 43 (Jackson 2009, p. 109; Chireau and Deutsch 2000, p. 75). What proved most profitable, however, and cemented their place on the cutting edge of Israeli culture was their Black American-styled Funk Band, "Soul Messengers from Dimona." With time, Western cultural critics would hail the Soul Messengers as the "Motown of the Middle East" because of their musical exploits. ${ }^{44}$ It is ironic that, at a time when Black Hebrews were, in many ways, fighting for recognition as more than just African Americans, what helped them endure was the global popularity of music tinged with an Afrocentric message.

\section{Sacrifice as Containment}

Having successfully contained both the Israeli Black Panthers and the Black Hebrews and benefitting from the self-destructive tendencies of Rabbi Kahane, whose belligerence and vitriol led himself and the JDL to implode under charges of domestic terrorism for another bombing plot, this time in Israel, Prime Minister Meir went into 1973 confident in her strategy for managing domestic radicalism and the troublesome issue of Blackness. For Israel, the final blow came from a call to close ranks as it faced an external threat. When Egypt and Syria launched a coordinated attack during Yom Kippur, one of Judaism's holiest days, in 1973, it silenced all internal issues. Overnight, Prime Minister Meir became a war leader. Shalom Cohen, who was instrumental in refashioning the Israeli Black Panthers into a mainstream party, put it the following way: "[B]ecause of the October War ... the main issues were no longer social or economic problems, but people were thinking about foreign affairs, about security. Our appeal as a party became secondary" (Cohen and Shemesh 1976, p. 19). The Meir administration's call for unity included everyone, including the Black Panthers:

It was only last night that the death toll of the Yom Kippur War was announced to the Israeli public. Today (7 November), families came to the cemeterieskibbutzniks and city dwellers, new immigrants and old established families, westerners, and Jews in the traditional dress of their Oriental countries of origin ... Families of Black Panthers from the slums of Jerusalem shared their grief side-by-side with affluent families from Tel Aviv, Mt. Carmel, and the wealthy suburb of Savion ... They heard ... the solemn words of Chief of Staff Gen[eral] David Elazar: 'The entire people of Israel in their hearts share the memory of its heroes with the bereaved families who may find consolation in their sons' devotion and sacrifice' ${ }^{45}$

Indeed, the Yom Kippur War even began the process of mending relations between Israel and the Black Hebrews, as the Israeli Defense Force (IDF) invited the Black Hebrews to perform for troops in the absence of being able to fight for the state ${ }^{46}$.

The crisis of Israeli Blackness ended abruptly. Given its urgency before the Yom Kippur War and the way it disappeared from the headlines, it seemed to signal the passing of one moment and the arrival of another. Across the globe, from Algeria to India, the drive for transnational solidarity and self-determination among communities of color would come up against the firewall of containment. Israel's confrontation with International Blackness, 
therefore, presaged a new era of geopolitics that neutralized social movements as the Cold War entered its final stage.

Funding: This research received no external funding.

Institutional Review Board Statement: Not applicable.

Informed Consent Statement: Not applicable.

Data Availability Statement: Not applicable.

Acknowledgments: I am grateful to David Stillman for translating the primary documents in Hebrew and Michael Robertson, David Blake, James Livingston, Norton Wheeler, and the anonymous reviewers for their invaluable feedback.

Conflicts of Interest: The author declares no conflict of interest.

\section{Notes}

Saadia Marciano cited in Amos Elon, “The Black Panthers of Israel,” New York Times, September 12, 1971.

Cited in a pamphlet from the Black Panthers of Israel, “Enough! Demonstration at City Hall!”, March 3, 1971, trans., Hebrew, The Israeli Left Archives, International Institute of Social History (Amsterdam). https://hdl.handle.net/10622/COLL00308.27 (accessed on 2 April 2020).

For literature on the Israeli Black Panther Party see (Bernstein 1984, pp. 129-52; Frankel 2012; Cohen and Shemesh 1976, pp. 19-22).

For scholarship on the Black Panther Party see (Seale 1970; Joseph 2006; Bloom and Martin 2013; Jones 2005; Ogbar 2005; Murch 2007, pp. 333-45).

Sometime Mizrahi, who are typically identified as North African Jews, is used interchangeably with Sephardi, who come from other parts of the non-Western Jewish diaspora. This paper uses Mizrahi to reflect how the activists referred to themselves in the documentation.

or literature on the history of the Black Hebrews/Hebrew Israelite community, see (Landing 2002; Sundquist 2005; Markowitz 1996, pp. 193-205; Chireau and Deutsch 2000; Miller 2020). For more on International Blackness, see (Winant 2001; Sing 1998, pp. 471-522; Gilroy 1993; Vitalis 2015; Lubin 2007, pp. 95-108). For literature on Black Panther internationalism, see (Lubin 2014; Feldman 2005; Malloy 2017; Wu 2013; Angelo 2009, pp. 17-35). For a history of Mizrahi identity and politics, see (Roby 2015; Shohat 2017; Massad 1996, pp. 53-68; Chetrit 2000, pp. 51-65; Ben-Dor 1997, pp. 60-67)

Counterpoint modernity see (Sundquist 2005).

David Ben Gurion quoted in (Chetrit 2009, p. 23).

Immigration agent cited in (Tonkin et al. 2016, p. 121).

Immigration agent quoted in (Segev 2018, p. 180).

Arye Gelblum cited in (Chetrit 2009, pp. 32-34; Shohat 2017, pp. 40-41).

Misha Rabinowitz quoted in (Segev 2018, p. 181).

Pardes Hanna Manifesto documented in (Roby 2015, p. 195).

David Horowitz quoted in (Segev 2018, p. 210).

Protest leaflet cited in (Roby 2015, pp. 136-37).

Rabbi Wentworth Arthur Matthew interview cited in Howard M. Brotz, "Negro 'Jews' in the United States", Phylon 13, No. 4 (December 1, 1952), p. 326.

Ben Ammi rearticulated the key elements of West African history to accommodate his cosmology and world view in Ben Ammi, God, the Black Man, and Truth (Takoma Park, MD: Communicators Press, 2008), p. 142.

American Jewish Agency. 198. David Glass Report to Israeli Minister of Interior. The Black Hebrews.” June 13, 1980, p. 9, American Jewish Congress Archives. http://www.ajcarchives.org/ajcarchive (accessed on 7 July 2020). For more on Black Hebrew culture, see (Brotz 1952, p. 332; Fernheimer 2009, p. 58). Ben Ammi quoted in Merrill Singer, "Symbolic Identity Formation in an African American Religious Sect: The Black Hebrew Israelites", in Chireau and Deutsch, p. 67.

Ben Ammi and the Black Hebrew made music central to the cultural story and theology of Hebrew Israelites in ways that borrowed from the historical experiences of African Americans, as he explained in Ben Ammi, God, the Black Man, and Truth (Takoma Park, MD: Communicators Press, 2008), p. 42. 
As Ben Ammi explained in God, the Black Man, and Truth (Takoma Park, MD: Communicators Press, 2008), p. 13.

Interview with Minister Ahmadiel Ben Yehuda cited in Ariel Dominique Hendelman. The Lost and Found Tribe: Inside the African Hebrew Israelite community of Dimona. Jerusalem Post. 17 December 2017. https:/ /www.jpost.com/magazine/lost-andfound-514965 (accessed on 24 June 2020).

George Gruen letter, “Black Hebrews," 10 December 1986, American Jewish Committee, 2, American Jewish Archives, http: / / collections.americanjewisharchives.org/ms/ms0603/ms0603.066.010.pdf (accessed on 9 July 2020)

US news media reported the rapidly increasing number of Black Hebrews seeking entrance to Israel and the alarm their presence caused among Israeli officials as Richard Elder, reported for the New York Times. Richard Eder. 1971. Black 'Israelites' Challenging Israel's Policies. New York Times. August 31, p. 3. https://www.proquest.com/historical-newspapers/blackisraelites-challenging-israels-policies/docview/119165485/se-2?accountid=10216. (accessed on 17 July 2020).

Pamphlet translated from Hebrew. Israeli Black Panthers. March 1971. The Israeli Left Archives. International Institute of Social History (Amsterdam). https:/ /hdl.handle.net/10622/COLL00308.65 (accessed on 2 April 2020).

Special report on the status of Israel from the American Jewish Committee. American Jewish Congress. 1971. Israeli Style Black Panthers. March 1971, pp. 8-9. American Jewish Congress Archives. http:/ / www.ajcarchives.org/ajcarchive (accessed on 9 July 2020).

SNCC Newsletter. 1967. Third World Roundup: The Palestine Problem. June-July, pp. 4-5. Civil Rights Movement Archive. https:/ / www.crmvet.org/docs/sv/6707_sncc_news-r.pdf (accessed on 7 July 2020).

Carmichael cited in Lewis Young, "American Blacks and the Arab-Israeli Conflict", p. 78.

The Black Panther Party. Mao Condemns U.S.-Israel Link. The Black Panther Newsletter. 16 November 1968, p. 9. Marxists Internet Archive. https:/ /www.marxists.org/history/usa/pubs/black-panther/02n012-14-Nov\%2016\%201968.pdf (accessed on 17 July 2020).

Huey P. Newton. Press Conference. 1970. The Black Panther Newsletter. September 5, p. 16. Marxists Internet Archive. https:/ / www.marxists.org/history/usa/pubs/black-panther/05\%20no\%2010\%201-28\%20sep\%205\%201970.pdf (accessed on 17 July 2020).

Martin Gansberg. 1970. Williamsburg Violence Reflects Tension in Area: Kahane, Released by Police, Says Hasidim Asked Aid from the J.D.L. New York Times, June 30, p. 45. https:/ / www.proquest.com/historical-newspapers/williamsburg-violencereflects-tension-area/docview /118803002/se-2?accountid=10216 (accessed on 17 July 2020).

Federal Bureau of Investigation. Vault files on Meir Kahane. Part 2 of 14, p. 49. https://vault.fbi.gov/meir-kahane/meir-kahanepart-02-of-14/view (accessed on 21 July 2020).

Jewish Telegraphic Agency. Daily News Bulletin. Kahane: Defend Israel's Honor Against Insults from Black Hebrews. 15 October 1971, p. 2. Jewish Telegraphic Agency Archive. https:/ /www.jta.org/1971/10/15/archive/kahane-defend-israels-honor-againstinsults-from-black-hebrews (accessed on 21 July 2020).

Reuven Aberjil interview, Center for Israel Education, Israel State Archives. https://israeled.org/israeli-black-panthers/ (accessed on 15 May 2020).

Charlie Biton interview quoted in Sami Shalom Chetrit, Intra-Jewish Conflict in Israel, p. 107.

For more context on the exchange see, Golda Meir Letter to Shaul Ben-Shimon (trans from Hebrew), November 1, 1971, The Israel State Archives. https:// docs.google.com/file/d/0BxpR2lHZaDkHaUR2eTBTWUtaa2M/edit (accessed on 15 May 2020); Shaul Ben-Shimon letter to Golda Meir (trans from Hebrew), November 5, 1971, The Israel State Archives. https: //docs.google.com/file/d/0BxpR2lHZaDkHc1M5dWJyb2dweW8/edit (accessed on 15 May 2020).

Cited in David Geller, American Jewish Committee of Jerusalem, Reports from Israel, "The Black Israelite Affair", 5 December 1971, p. 6, American Jewish Congress. http:/ / www.ajcarchives.org/ajcarchive (accessed on 10 July 2020).

Cited in David Glass Report to Israeli Minister of Interior, "The Black Hebrews", 13 June 1980, p. 11, American Jewish Congress Archives. http:/ / www.ajcarchives.org/ajcarchive (accessed on 9 July 2020).

American Jewish Congress. David Glass Report to Israeli Minister of Interior. The Black Hebrews. 13 June 1980, p. 11. American Jewish Congress Archives. http:/ / www.ajcarchives.org/ajcarchive (accessed on 9 July 2020).

Interview with Prince Heskiyahoo [sic] (Charles Blackwell), Other Sounds, 2014. http:/ /othersounds.com/interview-princeheskiyahoo-of-the-soul-messengers / (accessed on 17 April 2020). For the significance of music to Black Hebrews, see also Ethan Michaeli, "Another Exodus", p. 85.

Jewish Telegraphic Agency. Daily News Bulletin. All Israel Wept for Soldiers Who Fell in the Yom Kippur War. 8 November 1973, p. 3. Jewish Telegraphic Agency Archives. https:/ /www.jta.org/1973/11/08/archive/all-israel-wept-for-soldiers-who-fell-inthe-yom-kippur-war (accessed on 21 July 2020).

American Jewish Congress. David Glass Report to Israeli Minister of Interior. The Black Hebrews. 13 June 1980, p. 16. American Jewish Congress Archives. http:/ / www.ajcarchives.org/ajcarchive (accessed on 9 July 2020). 


\section{References}

Angelo, Anne-Marie. 2009. The Black Panthers in London, 1967-1972: A Diasporic Struggle Navigates the Black Atlantic. Radical History Review 103: 17-35. [CrossRef]

Ben-Dor, Zvi. 1997. A Short History of the Incredible Mizrahi History. News from Within. 8: 60-67.

Bernstein, Deborah. 1984. Conflict and Protest in Israeli Society: The Case of the Black Panthers of Israel. Youth and Society 16: 129-52. [CrossRef]

Blain, Keisha. 2017. Set the World on Fire: Black Nationalist Women and the Global Struggle for Freedom. Philadelphia: University of Pennsylvania Press.

Bloom, Joshua, and Waldo Martin. 2013. Black against Empire: The History and Politics of the Black Panther Party. Berkeley: University of California Press.

Brotz, Howard M. 1952. Negro 'Jews' in the United States. Phylon 13: 4. [CrossRef]

Chetrit, Sami Shalom. 2000. Mizrahi Politics in Israel: Between Integration and Alternative. Journal of Palestinian Studies 29: 51-65. [CrossRef]

Chetrit, Sami Shalom. 2009. Intra-Jewish Conflict in Israel: White Jews, Black Jews. New York: Routledge.

Chireau, Yvonne, and Nathaniel Deutsch, eds. 2000. Black Zion: African American Religious Encounters with Judaism. New York: Oxford University Press.

Cohen, Shalom, and Kokhavi Shemesh. 1976. The Origin and Development of the Israeli Black Panther Movement. Middle East Research and Information Project July: 19-22.

Feldman, Keith. 2005. A Shadow Over Palestine: The Imperial Life of Race in America. Minneapolis: The University of Minnesota Press.

Fernheimer, Janice. 2009. Black Jewish Identity Conflict: A Divided Universal Audience and the Impact of Dissociative Disruption. Rhetoric Society Quarterly 39: 46-72. [CrossRef]

Frankel, Oz. 2012. The Black Panthers of Israel and the Politics of Radical Analogy. In Black Power Beyond Borders: The Global Dimensions of the Black Power Movement. Edited by Nico Slate. New York: Palgrave Macmillan.

Gilroy, Paul. 1993. The Black Atlantic: Modernity and Double Consciousness. Cambridge: Harvard University Press.

Jackson, John L. 2009. All Yah's Children: Emigrationism, Afrocentrism, and the Place of Israel in Africa. Civilisations: Revue internationale d'anthropologie et de sciences. Humaines 58: 1. [CrossRef]

Jones, Charles. 2005. The Black Panther party (Reconsidered). Baltimore: Black Classic Press.

Joseph, Penial. 2006. Waiting Til the Midnight Hour: A Narrative History of Black Power in America. New York: Henry Holt.

Kaplan, Amy. 2018. Our American Israel: The Story of An Entangled Alliance. Cambridge: Harvard University Press.

Key, Andre E. 2014. Toward a Typology of Black Hebrew Religious Thought and Practice. Journal of Africana Religions 2: 31-66. [CrossRef]

Kurtis, Bill. 1981. Strangers in the Holy Land. New York Times Magazine, March 22.

Landing, James E. 2002. Black Judaism: Story of an American Movement. Durham: Carolina Academic Press.

Lee, Christopher J. 2010. Making the World After Empire: The Bandung Moment and its Political Afterlives. Athens: Ohio University Press.

Lubin, Alex. 2007. Locating Palestine in Pre-1948 Black Internationalism. Souls 9: 95-108. [CrossRef]

Lubin, Alex. 2014. Geographies of Liberation: The Making of an Afro-Arab Political Imaginary, Kindle ed. Chapel Hill: University of North Carolina Press.

Malloy, Sean. 2017. Out of Oakland: Black Panther Party Internationalism During the Cold War. Ithaca: Cornell University Press.

Markowitz, Fran. 1996. Israel as Africa, Africa as Israel: 'Divine Geography' in the Personal Narratives and Community Identity of the Black Hebrew Israelites. Anthropological Quarterly 69: 193-205. [CrossRef]

Massad, Joseph. 1996. Zionism's Internal Others: Israel and the Oriental Jews. Journal of Palestine Studies. 25: 53-68. [CrossRef]

McAlister, Melanie. 2001. Epic Encounters: Culture, Media, and US Interests in the Middle East, 1945-2000. Berkeley: University of California Press.

Miller, Michael T. 2020. The African Hebrew Israelites of Jerusalem and Ben Ammi's Theology of Marginalisation and Reorientation. Religions 11: 87. [CrossRef]

Murch, Donna. 2007. The Campus and the Street: Race, Migration, and the Origins of the Black Panther Party in Oakland, CA. Souls 9: 333-45. [CrossRef]

Ogbar, Jeffrey. 2005. Black Power: Radical Politics and African American Identity. Baltimore: The Johns Hopkins University Press.

Phillip, McCandish. 1969. Jewish Militants Step Up Activity: Paramilitary Skills Stressed-B'NAI B’RITH Critical. New York Times, June 25. Available online: https://www.proquest.com/historical-newspapers/jewish-militants-step-up-activity/docview/1187 02579 /se-2?accountid=10216 (accessed on 17 July 2020).

Prashad, Vijay. 2007. The Darker Nations of the World: A People's History of the Third World. New York: The New Press.

Ravitch, Diane. 2000. The Great School Wars: A History of New York Public Schools. Baltimore: The Johns Hopkins University Press.

Rebhun, Uzi, and Chaim Waxman. 2000. The 'Americanization' of Israel: A Demographic, Cultural, and Political Evaluation. Israel Studies 5: 65-91. [CrossRef]

Roby, Bryan K. 2015. The Mizrahi Era of Rebellion: Israel's Forgotten Civil Rights Struggle, 1948-1966. Syracuse: Syracuse University Press. Seale, Bobby. 1970. Seize the Time: The Story of the Black Panther Party. London: Arrow.

Segev, Tom. 2018. 1949: The First Israelis. New York: Free Press.

Shahak, Israel. 1973. Who is a Jew. Journal of Palestinian Studies 2: 151-56. 
Shohat, Ella. 1997. Mizrahim in Israel: Zionism from the Standpoint of its Jewish Victims. Social Texts 19/20: 29-48.

Shohat, Ella. 2017. On the Arab-Jew, Palestine, and Other Displacements: Selected Writings of Ella Shohat. London: Pluto Press.

Sing, Nikhil Pal. 1998. Culture/Wars: Recoding Empire in an Age of Democracy. American Quarterly 50: 471-522. [CrossRef]

Sundquist, Eric. 2005. Strangers in the Land: Blacks, Jews, Post-Holocaust America. Cambridge: Harvard University Press.

Tonkin, Elizabeth, Maryon McDonald, and Malcolm Chapman, eds. 2016. History and Ethnicity. London: Routledge.

Vitalis, Robert. 2015. White World Order, Black Power Politics: The Birth of American International Relations. Ithaca: Cornell University Press.

Weisbord, Robert G. 1975. Israel and the Black Hebrew Israelites. Judaism 24: 23-38.

Winant, Howard. 2001. The World is a Ghetto: Race and Democracy Since WWII. New York: Basic Books.

$\mathrm{Wu}$, Judy Tzu-Chun. 2013. Radicals on the Road: Internationalism, Orientalism, Feminism during the Vietnam Era. Ithaca: Cornell University Press.

Young, Lewis. 1972. American Blacks and the Arab-Israeli Conflict. Journal of Palestine Studies 2: 70-85. [CrossRef] 